\title{
WASTE PLANT MATERIAL AS A POTENTIAL ADSORBENT OF A SELECTED AZO DYE
}

\author{
Elwira Tomczak*, Paweł Tosik \\ Lodz University of Technology, Faculty of Process and Environmental Engineering, 90-924 Łódź, \\ Wólczańska 213, Poland
}

\begin{abstract}
This paper discusses the adsorption of Direct Orange 26 azo dye on sunflower husk - an agricultural waste product. During the study, sorption kinetics and equilibrium as well as sorption capacity of the husk were investigated. The adsorption kinetics was analyzed using pseudo-first and pseudo-second order equations, which indicated a chemical sorption mechanism. The sorption equilibrium was approximated with the two-parameter Freundlich and Langmuir equations and the three-parameter Redlich-Peterson equation. The main experiments were carried out in a laboratory adsorption column under different process conditions. Experimental data were interpreted with the Thomas model, based on the volumetric flow rate, initial composition of the feed solution and mass of the adsorbent. The results of modeling the adsorption equilibrium, adsorption kinetics and adsorption dynamics were evaluated statistically.
\end{abstract}

Keywords: sunflower husk, Direct Orange 26, adsorption equilibrium, adsorption kinetics, adsorption dynamics

\section{INTRODUCTION}

Textile industry wastewater, usually having a complex chemical composition with a significant share of dye substances, can negatively affect water resources as even small concentrations of dyes become discernible. Many dyes and compounds coming from their chemical transformation can possess carcinogenic and/or mutagenic properties and accumulate in living organisms. Dyes in natural waters reduce their transparency, impede photosynthesis, impair plant and animal growth, affect the solubility of oxygen and the self-cleaning process. There are many conventional (chemical and physical) methods of wastewater treatment reducing the concentration of dye contaminants (Avdicevic et al., 2017; Borges et al., 2016). They are often expensive and cause waste disposal problems. Among many available methods including coagulation, chemical deposition, ion exchange and membrane processes, adsorption gives the most promising results in terms of its economics and efficiency (Allen and Koumanova, 2003; Priya et al., 2014).

Activated carbons, zeolites and silica gels are the most popular adsorbents due to their high sorption capacity. Currently, however, there is also a demand for other efficient, but simultaneously cheap and easily available materials. These properties are characteristic of plant sorbents, whose lignocellulosic structure enables adsorption of many contaminants from water. To a great extent, plant sorbents are waste materials that do not generate additional costs and thus are becoming attractive substitutes for synthetic sorbents.

The available studies indicate an interest in new and inexpensive materials of plant origin to be used in biosorption processes. Biosorbents should effectively remove various contaminants from aqueous 
media, be non-toxic to the environment and easily recyclable. It is also important that the sorbent material be cheap and available in a given region (Hameed and Ahmad, 2009; Muthamilselvi et al., 2016; Nassar and El-Geundi, 1991; Soldatkina et al., 2009; Sud et al., 2008). The studies employing new biosorbents usually deal with sorption of heavy metal ions and dyes. Interestingly, some researchers use algae, bacteria, fungi, yeast as well as industrial and agricultural waste in order to sorb metal ions (Kotrba et al., 2011). Sorption capacities of selected biosorbents and wastes from food, wood and agricultural industries are presented in the work of Gala and Sanak-Rydlewska (2010). Also, similar natural sorbents of plant origin are used to adsorb dyes (Jain et al., 2009; Osma et al., 2007; Srinivasan and Viraraghavan, 2010; Tomczak et al., 2015). The experiments employing sunflower husk to remove dyes from the textile industry wastewater were described by Oguntimein and Duwane (2014) and Oguntimein (2016). The authors also proposed optimal conditions for the process and modification of the sorbent material increasing its adsorption capacity. In another study, sunflower husk was used to adsorb $\mathrm{Cu}^{+2}$ ions. The maximum sorption capacity of $57.14 \mathrm{mg} / \mathrm{g}$ was achieved at $30{ }^{\circ} \mathrm{C}$ and a pH of 5.0 (Witek-Krowiak, 2012). The optimization of known sorbent materials consists in searching for appropriate process parameters as well as possible modifications allowing the enhancement of their sorption capacity.

Another review (Crini, 2006) presents a critical analysis of low-cost materials, describes their characteristics, advantages and limitations, and discusses various mechanisms involved. The literature presents different values of sorption capacity for the same sorbent - sorbate systems. It depends on the origin, physical and chemical processing of the sorbent and the $\mathrm{pH}$ and temperature of the process. Some examples are summarized in Table 1.

Table 1. Sorption capacity of plant biosorbent with respect to certain dyes (Tomczak and Tosik, 2014)

\begin{tabular}{|c|c|c|}
\hline Dyes & Sorbent & $\begin{array}{l}\text { Maximum sorption } \\
\text { capacity, mg/g }\end{array}$ \\
\hline $\begin{array}{l}\text { Direct Red } 80 \\
\text { Direct Red } 81 \\
\text { Acid Blue } 92 \\
\text { Acid Red } 14 \\
\end{array}$ & Soy meal hulls & $\begin{array}{l}178.57 \\
120.48 \\
114.94 \\
109.89 \\
\end{array}$ \\
\hline Methylene Blue & $\begin{array}{c}\text { Duckweed } \\
\text { (Spirodela polyrhiza) }\end{array}$ & 112.36 \\
\hline Methylene Blue & Palm kernel fibre & 671.59 \\
\hline Methylene Blue & Wheat shells & 21.50 \\
\hline Methylene Blue & $\begin{array}{l}\text { Neem leaf powder } \\
\text { (Azadirachta indica) }\end{array}$ & 8.76 \\
\hline Methylene Blue & Rice husk & 40.58 \\
\hline Methylene Blue & Jute waste & 22.47 \\
\hline Methylene Blue & Banana peel & 20.80 \\
\hline Methylene Blue & Orange peel & 18.60 \\
\hline Direct Red 23 & Orange peel & 10.72 \\
\hline Direct Red 80 & Orange peel & 21.05 \\
\hline Reactive Orange 16 & Corn cob & 25.25 \\
\hline Acid Yellow 36 & Rice husk & 86.90 \\
\hline Direct Orange 26 & Rye straw & 22.00 \\
\hline Reactive Blue 81 & Rye straw & 14.00 \\
\hline
\end{tabular}


This work examines the possibility of removing Direct Orange 26 azo dye from water with the help of waste sunflower husk, which had been previously modified to improve the process performance. Sorption kinetics and equilibrium were investigated in batch experiments, and dynamics in a laboratory adsorption column via adjusting process parameters such as the initial dye concentration, volumetric flow rate of the feed solution and bed height. The resulting breakthrough curves were used to model the process mathematically with the Thomas equation.

\section{EXPERIMENTAL MATERIALS}

The adsorption of Direct Orange 26 was performed using sunflower husk obtained from domestic sunflower harvest (Helianthus annus L.) in 2015. Sunflower husk is a waste material produced through decorticating sunflower seeds (the price of $100 \mathrm{~kg}$ of husk is roughly $100 \mathrm{PLN}$ ). Due to its chemical composition and lignocellulosic structure, sunflower husk is not used by the food industry but can be used as a feed additive. It is built from cellulose (48\%), hemicellulose (35\%) and lignin (17\%) (Piyo, 2014). Cellulose and hemicellulose are polymers composed of sugars, while lignin is a biopolymer made up of phenol derivatives. Chemical structure of sunflower husk indicates its good sorption ability (Fig. 1).

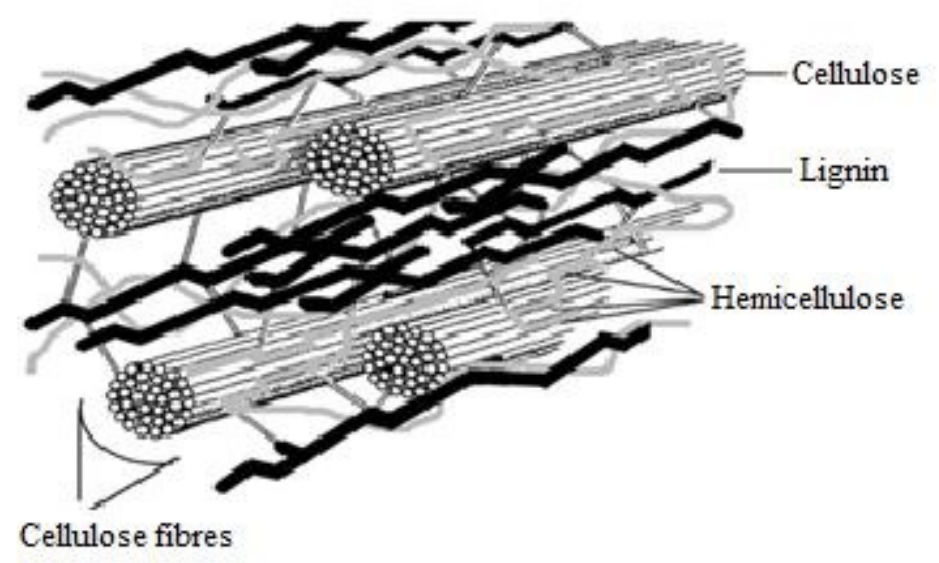

Fig. 1. Lignocellulosic complex (Leja et al., 2009)

The cell wall of a biosorbent is built mostly from polysaccharides, lipids and proteins containing numerous functional groups allowing the creation of a new bond, e.g. sorbent-dye bond. The functional groups responsible for bonding a substance include carboxyl, hydroxyl, sulfonyl, phosphate and amine groups (Volesky, 2007). Bonding between the sorbent and the solute can result from the weak van der Waals forces and strong interactions between the charged sulfonyl groups of the dye and the sorbent surface represented by the hydroxyl groups, according to the following mechanism (Sateu et al., 2011):

$$
\text { Husk }-\mathrm{OH}+\mathrm{H}^{+}+{ }^{-} \mathrm{O}_{3} \mathrm{~S}-\text { Dye }=\text { Husk }-\mathrm{OH}_{2}{ }^{+}+{ }^{-} \mathrm{O}_{3} \mathrm{~S}-\text { Dye }
$$

At first, the sunflower husk used in the experiments was washed and boiled for $2 \mathrm{~h}$ in a pressure cooker at $130{ }^{\circ} \mathrm{C}$. Then, for the purpose of enhancing its adsorption capacity the husk was modified by wet etching with $10 \% \mathrm{H}_{2} \mathrm{SO}_{4}$ performed for $6 \mathrm{~h}$ at $60{ }^{\circ} \mathrm{C}$. After the chemical treatment, the husk was dried for $2 \mathrm{~h}$ at $105^{\circ} \mathrm{C}$. The treatment procedure was developed after previous studies, in which the husk had only been washed. The investigations of sorption kinetics, dynamics and equilibrium were carried out at $25^{\circ} \mathrm{C}$ and a pH of 5 to 6 .

Direct Orange 26 of standardized purity, molecular formula $\mathrm{C}_{33} \mathrm{H}_{22} \mathrm{~N}_{6} \mathrm{Na}_{2} \mathrm{O}_{9} \mathrm{~S}_{2}$ and a molecular mass of $756.67 \mathrm{~g} / \mathrm{mol}$ was purchased from Boruta-Zachem Kolor company (Poland). The dye is widely used by 
the textile industry but also as a colour additive permitted for use in cosmetics and household products by the Minister of Health Regulation of 30 March 2005.

\section{SORPTION KINETICS}

Determination of sorption kinetics is a fundamental step in the assessment of sorbent usability. For this purpose, changes in concentration of the solute in both the feed solution and the adsorbent are measured as a function of time.

The sorption kinetics and sorption equilibrium experiments were performed simultaneously using the same laboratory setup. $5 \mathrm{~g}$ dry weight of the sorbent was added to $200 \mathrm{~cm}^{3}$ of the feed solution, containing $50-800 \mathrm{mg} / \mathrm{dm}^{3}$ of Direct Orange 26 . Afterwards, the flasks were mechanically shaken in a thermostated bath at $25^{\circ} \mathrm{C}$ until the adsorption equilibrium was reached. During the process, the concentration of Direct Orange 26 in the aqueous phase was measured using a UV-Vis Jasco V639 spectrophotometer at a wavelength of $494 \mathrm{~nm}$.

The decreasing concentration of Direct Orange 26 in the feed during the adsorption process corresponds to the amount of the dye adsorbed by the husk (Fig. 2), which can be calculated with Eq. (1):

$$
q=\frac{V}{m}\left(C_{0}-C\right)
$$

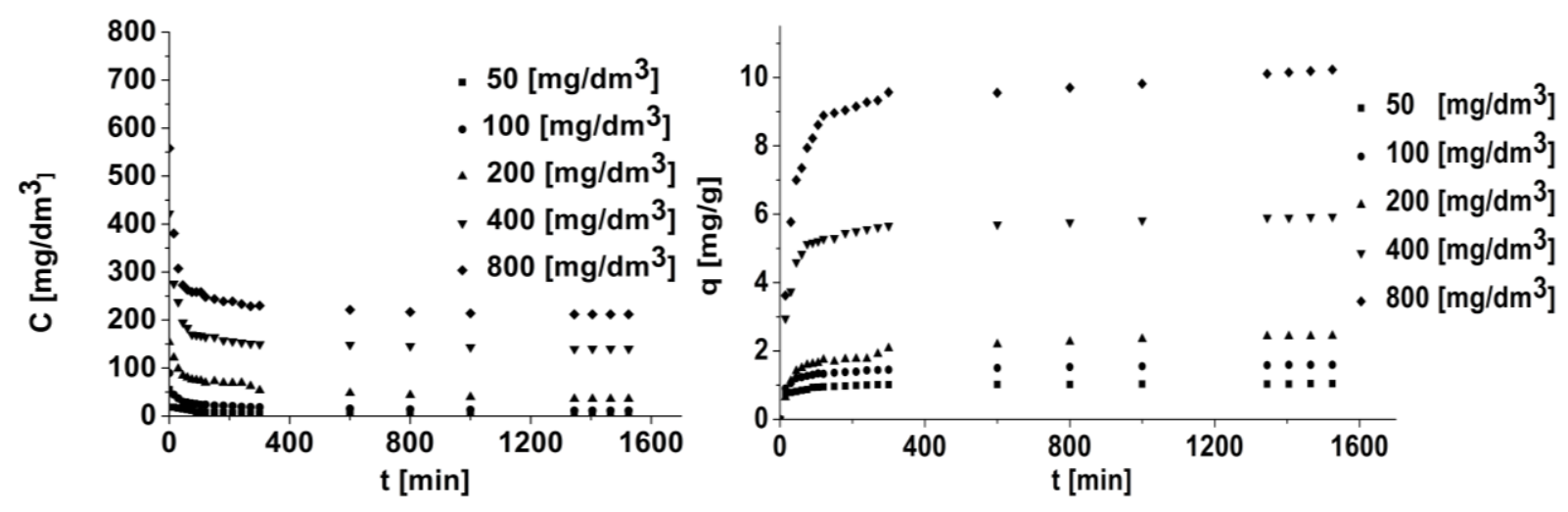

Fig. 2. Experimental data of sorption kinetics for the sunflower husk - Direct Orange 26 system

Chemical reaction kinetics allows to determine the process rate and thereby the pace of the expected concentration changes of the separated substance. The sorption kinetics is most often described using:

- the pseudo-first order Lagergren equation:

$$
\frac{d q}{d t}=k_{1}\left(q_{e}-q\right)
$$

- the pseudo-second order Ho and McKay equation:

$$
\frac{d q}{d t}=k_{2}\left(q_{e}-q\right)^{2}
$$

The models given by Eqs. (2) and (3) are frequently used (Ho and Wang, 2004; Ho, 2006; Sočo and Kalembkiewicz, 2016). When the adsorption mechanism is mainly physical, the kinetics is usually described with Eq. (2), which gives perfect approximation at lower equilibrium concentrations and poor 
approximation at higher concentrations. In the latter case, the psuedo-second order model given by Eq. (3) becomes preferable. This model assumes that chemisorption is the prevailing mechanism controlling the process.

Figure 3 compares the kinetic experimental data in the sunflower husk - Direct Orange 26 system at an initial feed concentration of $800 \mathrm{mg} / \mathrm{dm}^{3}$ with the estimated values calculated using Eqs. (2) and (3). The points on the graph represent the experimental data while the solid lines reflect the approximations obtained with both models. The calculated $R^{2}$ values show that the psuedo-second order model provides more accurate results, which suggests that the sorption mechanism is of chemical rather than physical nature.

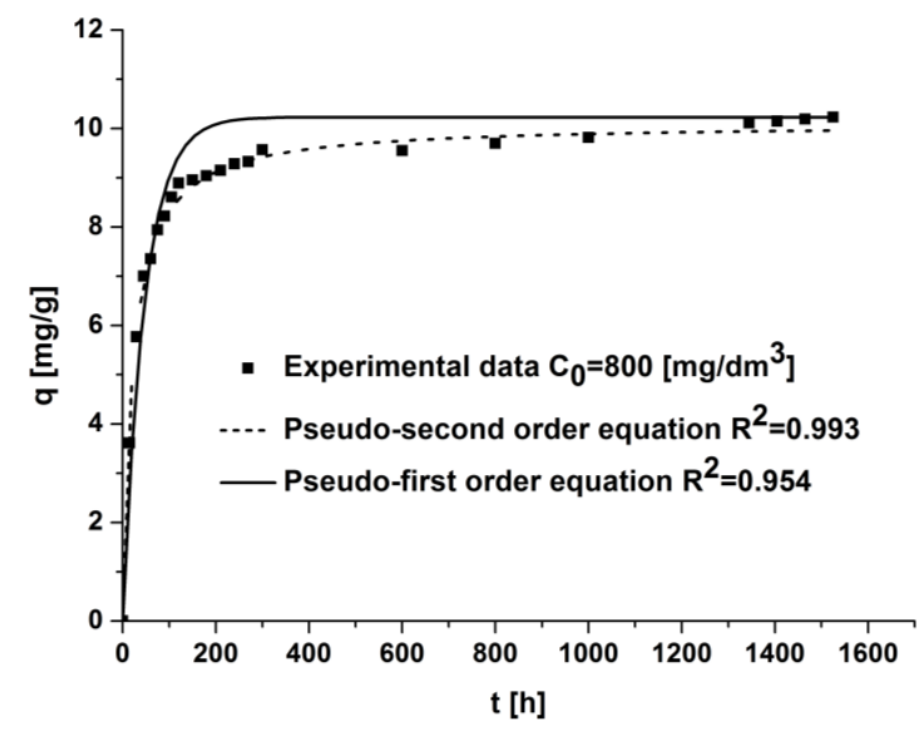

Fig. 3. Mathematical description of sorption kinetics for the sunflower husk - Direct Orange 26 system

\section{SORPTION EQUILIBRIUM}

Determination of the equilibrium between a sorbent and a solute at constant temperature, termed as a sorption isotherm, is of fundamental significance in sorption studies. The equilibrium is reached when the rate of adsorption is equal to the rate of desorption. As a result, a relation is obtained between the concentration of the separated substance in the sorbent material $q_{e}[\mathrm{mg} / \mathrm{g}$ dry weight] and its concentration in the feed solution $C_{e}\left[\mathrm{mg} / \mathrm{dm}^{3}\right]$. The equilibrium study allows recognition of the sorption capacity of a given material. Commonly, the following equations are used with regard to the solid-liquid equilibrium:

- Freundlich equation

$$
q_{e}=K_{F} C_{e}^{1 / n}
$$

- Langmuir equation

$$
q_{e}=\frac{q_{m} K_{L} C_{e}}{1+K_{L} C_{e}}
$$

- Redlich-Peterson equation

$$
q_{e}=\frac{q_{m} K_{R P} C_{e}}{1+K_{R P} C_{e}^{n}}
$$

The approximation results obtained with Eqs. (4) - (6) at $C_{0}=800 \mathrm{mg} / \mathrm{dm}^{3}$ are presented in Fig. 4. 


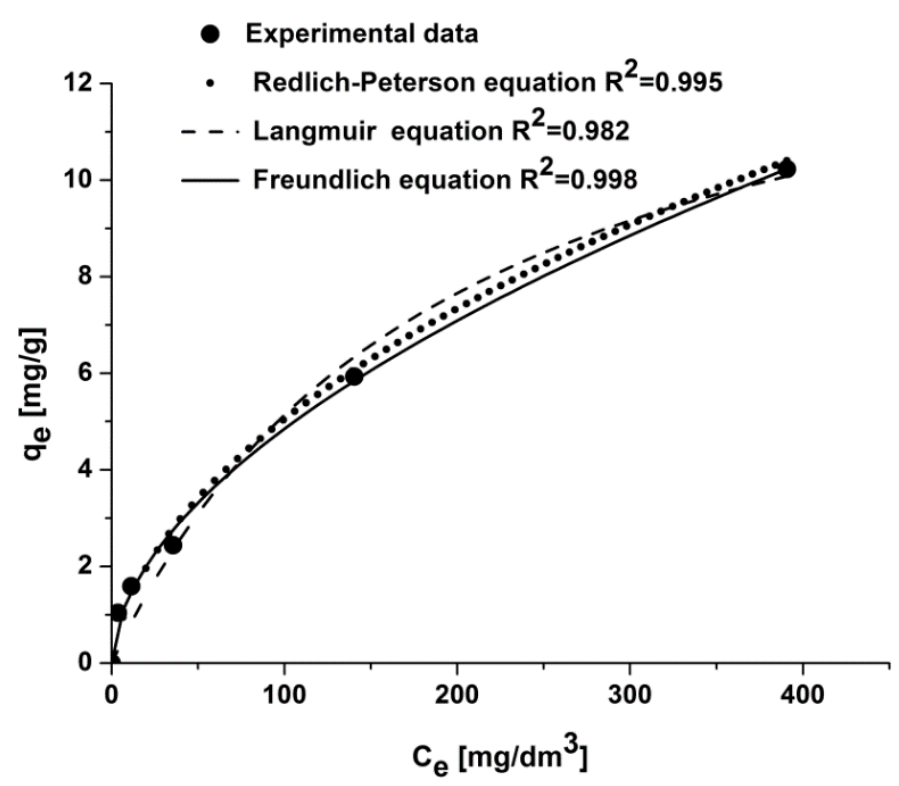

Fig. 4. Mathematical description of sorption equilibrium for the sunflower husk - Direct Orange 26 system

The respective equation parameters were determined with the simplex algorithm using Origin 7 software. In Table 2 values of coefficients for Eqs $4-6$ are presented. Statistical analysis shows that all three equations give similar results, although the Freundlich isotherm seems to be the most accurate.

Table 2. Values of coefficients for Equations $(4) \div(6)$

\begin{tabular}{|l|l|}
\hline Equation & Coefficients \\
\hline Freuendlich & $K_{F}=0.389 ; 1 / n=0.548$ \\
\hline Langmuir & $K_{L}=0.517 \cdot 10^{-2} ; q_{m}=15.066$ \\
\hline Redlich - Peterson & $K_{R P}=0.487 ; q_{m}=0.682 ; n=0.530$ \\
\hline
\end{tabular}

\section{SORPTION DYNAMICS}

Adsorption dynamics studies were performed in a glass column of $3.45 \cdot 10^{-3} \mathrm{~m}$ diameter and $0.70 \mathrm{~m}$ length. The column was filled with dry sunflower husk of $453 \mathrm{~kg} / \mathrm{m}^{3}$ density. The feed solution was pumped upwards through the bed using a metering pump and removed from the top of the column. At specified time intervals, samples were taken at the column outlet and analyzed with the UV-Vis Jasco V630 spectrophotometer. The feed temperature and $\mathrm{pH}$ were stabilized at $25^{\circ} \mathrm{C}$ and 5.8 , respectively. In order to evaluate the proposed adsorption model, experiments had to be performed varying the process parameters. For this reason, the following quantities were combined: solute concentration of 50 and $75 \mathrm{mg} / \mathrm{dm}^{3}$, feed flow rate of $50,100,200$ and $400 \mathrm{~cm}^{3} / \mathrm{h}$, bed height of $0.580,0.435,0.290$ and $0.145 \mathrm{~m}$ corresponding to the mass of sunflower husk equal to $145,108,72.5$ and $36.25 \mathrm{~g}$, respectively.

Approximations of the experimental results were performed with the Thomas model (Garba et al., 2016; Ghribi and Chlendi, 2011; Kocadagistan and Kocadagistan, 2016; Lambrecht et al. 2015; Mahendra et al., 2015; Mustafa and Ebrahim, 2010; Xu et al., 2013), which does not rely on the internal and external mass transfer resistance and omits the axial dispersion phenomenon:

$$
\ln \left(\frac{C_{0}}{C}-1\right)=\frac{K_{T} \cdot q \cdot m}{Q}-K_{T} \cdot C_{0} \cdot t
$$


For the purpose of finding the equation coefficients, the $\ln \left(\left(C_{0} / C_{t}\right)-1\right)$ expression values were plotted versus time. Coefficients a and $\mathrm{b}$ were determined from the linear approximation of experimental data, while coefficients $K_{T}$ and $q_{0}$ were estimated with the following formulas:

$$
\begin{gathered}
K_{T}=\frac{-a}{C_{0}} \\
q=\frac{b \cdot Q}{K_{T} \cdot m}
\end{gathered}
$$

The calculated values of the coefficients are given in Table 3. The experimental results were interpreted using the breakthrough curves generated with the Thomas model in accordance with the equation:

$$
C=\frac{1}{1+\exp \left(\frac{K_{T} \cdot q \cdot m}{Q}\right)-K_{T} \cdot C_{0} \cdot t} \cdot C_{0}
$$

Table 3. Values of $K_{T}$ and $q_{0}$ calculated for $C_{0}=50 \mathrm{mg} / \mathrm{dm}^{3}$ and $75 \mathrm{mg} / \mathrm{dm}^{3}$ at different feed flow rates

\begin{tabular}{|c|c|c|c|c|}
\hline Flow rate & $Q=400, \mathrm{~cm}^{3} / \mathrm{h}$ & $Q=200, \mathrm{~cm}^{3} / \mathrm{h}$ & $Q=100, \mathrm{~cm}^{3} / \mathrm{h}$ & $Q=50, \mathrm{~cm}^{3} / \mathrm{h}$ \\
\hline \multicolumn{5}{|c|}{$C_{0}=50 \mathrm{mg} / \mathrm{dm}^{3}$} \\
\hline$K_{T}, \mathrm{~cm}^{3} /(\mathrm{mg} \cdot \mathrm{h})$ & $5.2 \times 10^{-3}$ & $1.8 \times 10^{-3}$ & $1.2 \times 10^{-3}$ & $5.0 \times 10^{-4}$ \\
\hline$q, \mathrm{mg} / \mathrm{g}$ & 2.34 & 2.72 & 2.54 & 3.53 \\
\hline \multicolumn{5}{|c|}{$C_{0}=75 \mathrm{mg} / \mathrm{dm}^{3}$} \\
\hline$K_{T}, \mathrm{~cm}^{3} /(\mathrm{mg} \cdot \mathrm{h})$ & $5.2 \times 10^{-3}$ & $1.1 \times 10^{-3}$ & $1.0 \times 10^{-3}$ & $2.3 \times 10^{-4}$ \\
\hline$q, \mathrm{mg} / \mathrm{g}$ & 2.04 & 4.61 & 3.34 & 6.47 \\
\hline
\end{tabular}

\section{COLUMN ADSORPTION RESULTS}

Figure 5 presents changes in the dye concentration at outlet of column versus time, recorded at different feed flow rates, i.e. $Q=400 \mathrm{~cm}^{3} / \mathrm{h}, Q=200 \mathrm{~cm}^{3} / \mathrm{h}, Q=100 \mathrm{~cm}^{3} / \mathrm{h}$ and $Q=50 \mathrm{~cm}^{3} / \mathrm{h}$, different initial concentrations, i.e. $C_{0}=50 \mathrm{mg} / \mathrm{dm}^{3}$ and $C_{0}=75 \mathrm{mg} / \mathrm{dm}^{3}$, and an adsorbent bed height of $0.58 \mathrm{~m}$.

Analysis of the graphs allowed determination of breakthrough and saturation time (for the dye concentrations equal to $0.05 C_{0}$ and $0.95 C_{0}$ ). The results are summarized in Table 4 .

The breakthrough time and the saturation time are influenced by such process parameters as the adsorbent bed height, feed flow rate and initial dye concentration in the influent stream. Both the breakthrough time and the saturation time increase with decreasing flow rate, decreasing dye concentration and increasing bed height.

Figure 6 illustrates the changes in the outlet composition against time at $Q=50 \mathrm{~cm}^{3} / \mathrm{h}$ measured for four different bed heights. Figure 7 shows the changes in outlet composition against time measured at constant bed height of $0.58 \mathrm{~m}$ and constant $C_{0}=50 \mathrm{mg} / \mathrm{dm}^{3}$ for four different feed flow rates. The points on the graphs correspond to the experimental values while the solid lines were generated with the Thomas model. 

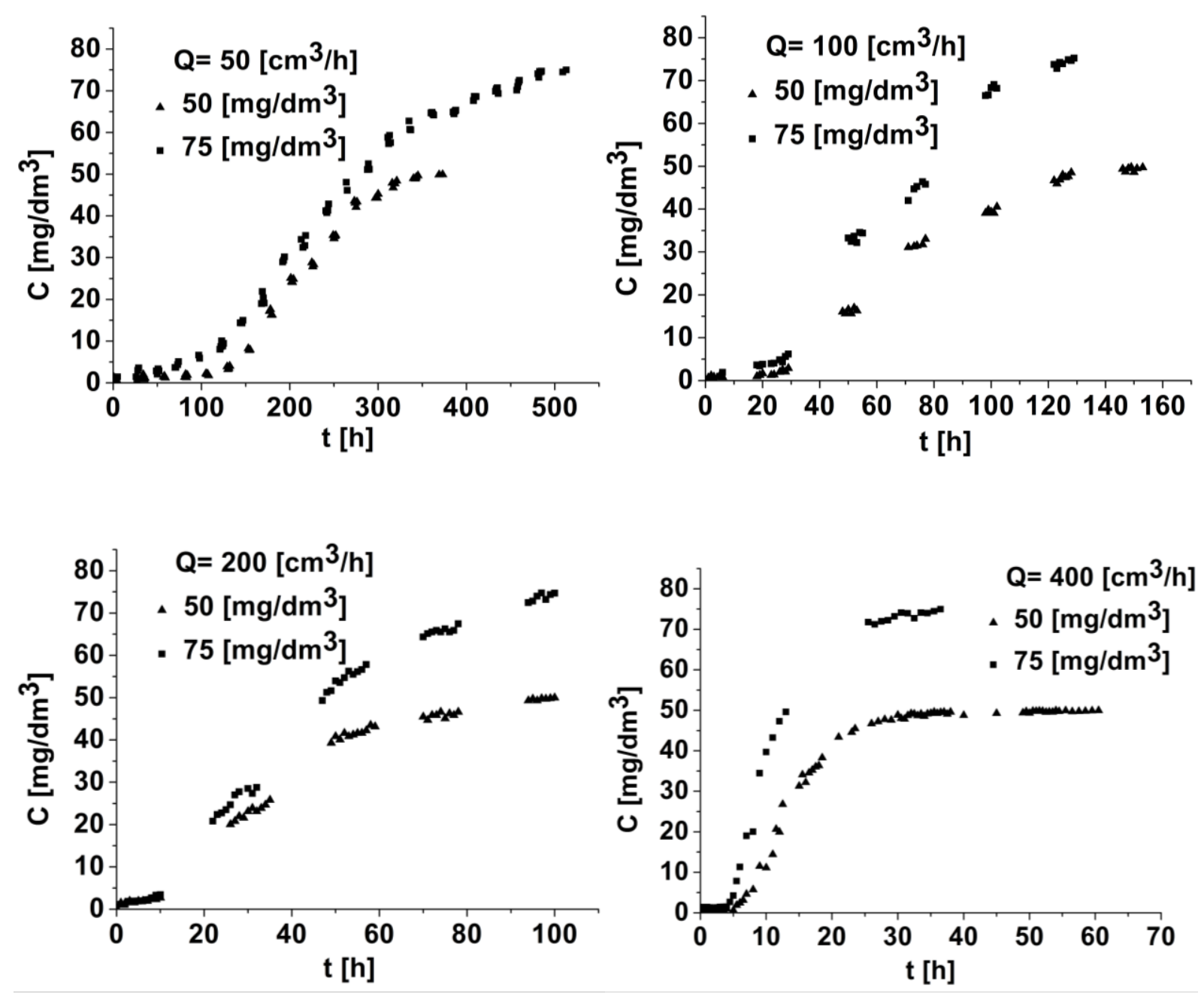

Fig. 5. The breakthrough curves - changes in the dye concentration versus time at $Q=50 \mathrm{~cm}^{3} / \mathrm{h}, Q=100 \mathrm{~cm}^{3} / \mathrm{h}, Q=200 \mathrm{~cm}^{3} / \mathrm{h}$ and $Q=400 \mathrm{~cm}^{3} / \mathrm{h}$

Table 4. Breakthrough time and saturation time at different feed flow rates

\begin{tabular}{|c|c|c|}
\hline $\begin{array}{c}\text { Feed flow rate at } \\
C_{0}=50 \mathrm{mg} / \mathrm{dm}^{3}\end{array}$ & $\begin{array}{c}\text { Breakthrough time } \\
0.05 C_{0}=2.5 \mathrm{mg} / \mathrm{dm}^{3}\end{array}$ & $\begin{array}{c}\text { Saturation time } \\
0.95 C_{0}=47.5 \mathrm{mg} / \mathrm{dm}^{3}\end{array}$ \\
\hline$Q, \mathrm{~cm}^{3} / \mathrm{h}$ & $t_{B}, \mathrm{~h}$ & $t_{S}, \mathrm{~h}$ \\
\hline 400 & 6 & 27.5 \\
\hline 200 & 9.5 & 80 \\
\hline 100 & 27 & 126 \\
\hline 50 & 118 & 310 \\
\hline Feed flow rate at & Breakthrough time & Saturation time \\
$C_{0}=75 \mathrm{mg} / \mathrm{dm}^{3}$ & $0.05 C_{0}=3.75 \mathrm{mg} / \mathrm{dm}^{3}$ & $0.95 C_{0}=71.25 \mathrm{mg} / \mathrm{dm}^{3}$ \\
\hline$Q, \mathrm{~cm}^{3} / \mathrm{h}$ & $t_{B}, \mathrm{~h}$ & 26.5 \\
\hline 400 & 4.5 & 90 \\
\hline 200 & 12 & 120 \\
\hline 100 & 20 & 458 \\
\hline 50 & 71 & \\
\hline & & $t_{S}$ \\
\hline
\end{tabular}




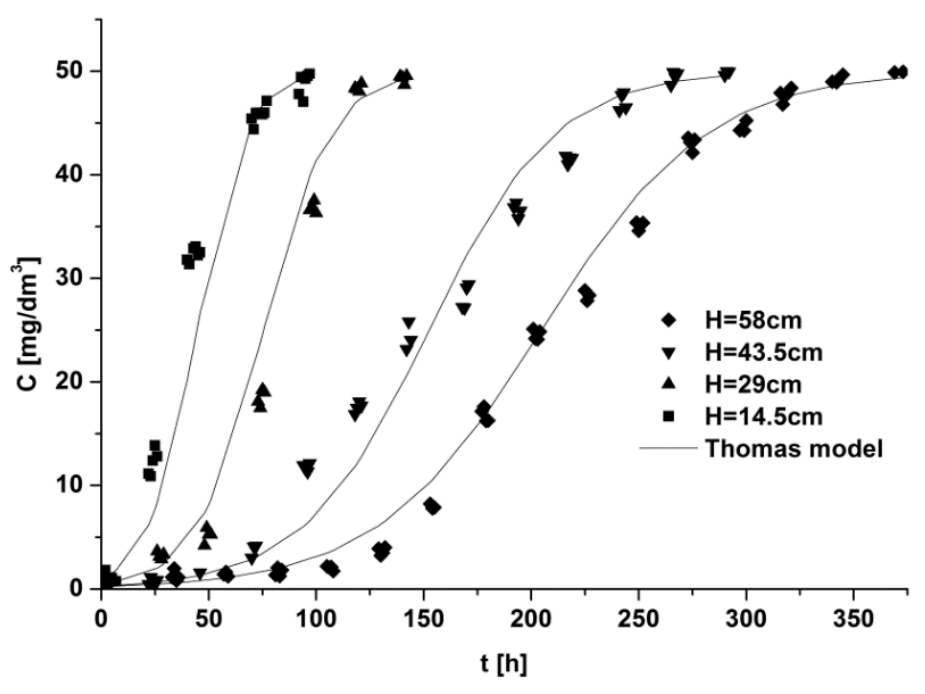

Fig. 6. The breakthrough curves - changes in the outlet dye concentration versus time at different bed heights

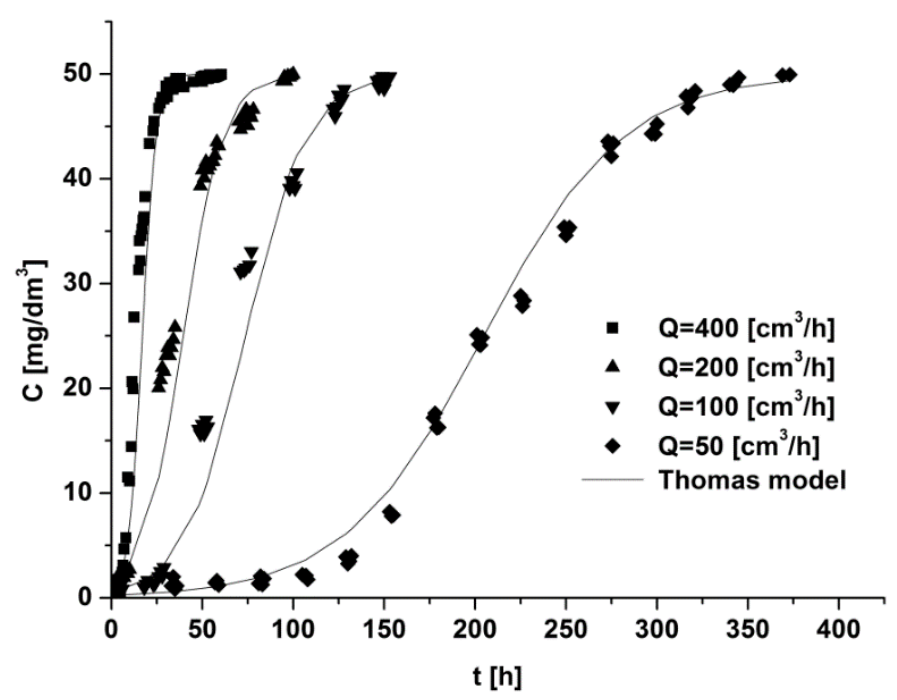

Fig. 7. The breakthrough curves - changes in the outlet dye concentration versus time at different feed flow rates

Figures 6 and 7 indicate that the Thomas model can successfully be used to estimate dye concentration at the column outlet. However, in order to characterize sorption dynamics in the adsorption column, a column mass balance is necessary, in its simple or modified form, as suggested elsewhere (Babu and Gupta, 2005; Chen et al., 2003; Tomczak, 2013).

\section{SUMMARY}

The paper analyzes sorption kinetics, dynamics and equilibrium in the laboratory adsorption column employed to remove Direct Orange 26 from aqueous media. To separate the dye, modified sunflower husk was used due to its availability and inexpensiveness. The aim of modification was to enhance the adsorption capacity of the husk.

In summary, sunflower husk is a useful sorption material, which can be utilized for textile wastewater treatment. A sorption capacity of $11 \mathrm{mg} / \mathrm{g}$ dry weight was achieved when the initial dye concentration in the feed was equal to $800 \mathrm{mg} / \mathrm{dm}^{3}$. 
The adsorption kinetics was successfully modeled using the pseudo-first order Lagergren and the pseudo-second order Ho and McKay formulas. However, better results were obtained with the latter equation, which suggests a chemisorption mechanism.

For the purpose of characterizing the sorption equilibrium, the two-parameter Freundlich and Langmuir equations as well as the three-parameter Redlich-Peterson equation were proposed. In every case, experimental data were satisfactorily approximated, which was confirmed by statistical analysis.

The obtained breakthrough curves were further used to model the results with the Thomas equation. The performance of the adsorption column turned out to be a function of the investigated process parameters. When the bed height was constant, lowering the dye concentration and the feed flow rate resulted in longer breakthrough and saturation times.

\section{SYMBOLS}

$C \quad$ dye concentration in the feed, $\mathrm{mg} / \mathrm{dm}^{3}$

$C_{0} \quad$ initial dye concentration in the feed, $\mathrm{mg} / \mathrm{dm}^{3}$

$C_{e} \quad$ equilibrium solute concentration in the solution, $\mathrm{mg} / \mathrm{dm}^{3}$

$k_{1} \quad$ kinetic constant, $1 / \mathrm{s}$

$k_{2} \quad$ kinetic constant, $\mathrm{g} /(\mathrm{mg} \min )$

$K_{F} \quad$ Freundlich constant, $\mathrm{mg}^{1-1 / n} \mathrm{dm}^{3(1 / n)} / \mathrm{g}$

$1 / n \quad$ Freundlich constant

$K_{L} \quad$ Langmuir constant, $\mathrm{dm}^{3} / \mathrm{mg}$

$K_{R P} \quad$ Redlich-Peterson constant, $\left(\mathrm{dm}^{3} / \mathrm{mg}\right)^{n}$

$K_{T} \quad$ coefficient in Eq. (7), $\mathrm{cm}^{3} /(\mathrm{mg} \cdot \mathrm{h})$

$m \quad$ mass of the adsorbent, $\mathrm{g}$

$n \quad$ Redlich-Peterson constant

$q \quad$ amount of the dye adsorbed in the adsorbent, $\mathrm{mg} / \mathrm{g}$

$q_{e} \quad$ equilibrium amount of the dye adsorbed per unit mass of the adsorbent, $\mathrm{mg} / \mathrm{g}$

$q_{e} \quad$ equilibrium solute concentration in the adsorbent bed, $\mathrm{mg} / \mathrm{g}$

$q_{m} \quad$ sorption capacity, $\mathrm{mg} / \mathrm{g}$

$t_{B} \quad$ breakthrough time, $\mathrm{h}$

$t_{S} \quad$ saturation time, $\mathrm{h}$

V solution volume, $\mathrm{dm}^{3}$

\section{REFERENCES}

Allen S.J., Koumanova B., 2003. Decolourisation of water/wastewater using adsorption. J. Univ. Chem. Technol. Metallurgy. 40, 175-192.

Avdicevic M.Z., Kosutic K., Dobrovic S. 2017. Effect of operating conditions on the performances of multichannel ceramic UF membranes for textile mercerization wastewater treatment. Environ. Technol., 38, 65-77. DOI: 10.1080/09593330.2016.1186225.

Babu B.V., Gupta S., 2005. Modelling and simulation of fixed bed adsorption column: effect of velocity variation. J. Eng. Techn., 1, 60-66. DOI: 10.1016/30923-4748(05)00044-05.

Borges G.A., Silva L.P., Penido J.A., de Lemos L.R., Mageste A.B., Rodrigues G.D. 2016. A method for dye extraction using an aqueous two-phase system: Effect of co-occurrence of contaminants in textile industry wastewater. J. Environ. Manage., 183, 196-203. DOI: 10.1016/j.jenvman.2016.08.056.

Chen J.P., Yoon J.T., Yiadoumi S., 2003. Effects of chemical and physical properties of influence on copper sorption onto activated carbon fixe-bed columns. Carbon, 41, 1635-1644. DOI: 10.1016/S0008-6223(03)001179. 
Crini G., 2006. Non-conventional low-cost adsorbents for dye removal: a review. Bioresour. Technol. 97, 1061-85. DOI: 10.1016/j.biortech.2005.05.001.

Gala A., Sanak-Rydlewska S., 2010. Sorpcja jonów metali toksycznych z roztworów wodnych na odpadach naturalnych - przegląd literaturowy. Górnictwo i Geoinżynieria, 4(1), 49-59.

Garba A., Nasri N.S., Basri H., Ismail R., Majid Z.A., Hamza U.D., Mohammed J., 2016, Adsorptive removal of phenol from aqueous solution on a modified palm shell-based carbon: fixed-bed adsorption studies. Desalin. Wat. Treat., 57, 29488-29499. DOI: 10.1080/19443994.2016.1184187.

Ghribi A., Chlendi M., 2011. Modeling of fixed bed adsorption: Application to the adsorption of an organic dye. Asian J. Textile, 1, 161-171. DOI: 10.3923/ajt.2011.161.171.

Hameed B.H., Ahmad A.A., 2009. Batch adsorption of methylene blue from aqueous solution by garlic peel, an agricultural waste biomass. J. Hazard. Mat., 164, 870-875. DOI: 10.1016/j.jhazmat.2008.08.084.

Ho Y.S., 2006. Second-order kinetic model for the sorption of cadmium onto tree fern: A comparison of linear and non-linear methods. Wat. Res., 40, 119-125. DOI:10.1016/j.watres.2005.10.040.

Ho Y.S., Wang C.C., 2004. Pseudo-isotherms for the sorption of cadmium ion onto tree fern. Proc. Biochem., 39, 761-765. DOI:10.1016/S0032-9592(03)00184-5.

Jain M., Garga V.K., Kadirvelub K., 2009. Chromium(VI) removal from aqueous system using Helianthus annuus (sunflower) stem waste. J. Haz. Mat., 162(1), 365-372. DOI: 10.1016/j.jhazmat.2008.05.048.

Lambrecht R., Barros M.A.S.D., Arroyo P.A., Borba C.E., Silva E. A., 2015. Adsorption of the dye reactive blue 5g in retorted shale. Braz. J. Chem. Eng. 32, 269 - 281. DOI: 10.1590/0104-6632.20150321s00001715.

Leja K., Lewandowicz G., Grejek W., 2009. Produkcja bioetanolu z surowców celulozowych. Biotechnologia, 4(87), 88-101.

Kocadagistan B., Kocadagistan E., 2016. Batch and column removal of the dye blue 3R over pumice. Desalin. Wat. Treat., 57, 28042-28055. DOI: 10.1080/19443994.2016.1184186.

Kotrba P., Mackova M., Urbánek V. (Eds.), 2011. Microbial biosorption of metals. Springer Science+Business Media B.V. DOI: 10.1007/978-94-007-0443-5.

Mahendra Ch., Anand Babu, Satyasai P.M., K.K. Rajan. 2015. Application of the Thomas model for cesium ion exchange on AMP-PAN, In: Shirish Sonawan, Y. Pyde Setty, Srinu Nayak S. (Eds.), Chemical and Bioprocess Engineering: Trends and Developments. Chapter: 18. CRC press - A Taylor and Francis Group. DOI: 10.13140/2.1.3833.8561.

Mustafa Y.A., Ebrahim S.E., 2010. Utilization of Thomas model to predict the breakthrough curves for adsorption and ion exchange, J. Eng., 4(16), 6206-6223.

Muthamilselvi P., Karthikeyan R., Kumar B.S.M. 2016. Adsorption of phenol onto garlic peel: Optimization, kinetics, isotherm, and thermodynamic studies. Desalin. Water Treat., 57, 2089-2103. DOI: 10.1080/19443994.2014.979237.

Nassar M.M., El-Geundi M.S. 1991. Comparative cost of colour removal from textile effluents using natural adsorbents. J. Chem. Technol. Biotechnol., 50(2), 257-264. DOI: 10.1002/jctb.280500210.

Oguntimein G.B., Duwane T., 2014. The potential use of acid treated dried sunflower seed hull as a biosorbent for the removal of textile effluent dye from aqueous solution. Res. Inventy: Int. J. Eng. Sci., 4(7), 21-30.

Oguntimein G.B. 2016. Textile dye removal using dried sun flower seed hull a new low cost biosorbent: equilibrium, kinetics and thermodynamic studies. Adv. Res. Text Eng., 1(1), 1008-1014.

Osma J.F., Saravia V., Toca-Herrera J.L., Rodriguez Couto S., 2007. Sunflower seed shells: A novel and effective low-cost adsorbent for the removal of the diazo dye Reactive Black 5 from aqueous solutions. J. Haz. Mat., 147, 900-905. DOI: 10.1016/j.jhazmat.2007.01.112.

Piyo N., 2014. Liquefaction of sunflower husks for biochar production, Master degree dissertation, North-West University, South Africa.

Priya R., Nithya R., Anuradha R., Kamachi T., 2014. Removal of colour from crystal violet dye using low cost adsorbents. Int. J. Chem. Tech. Res., 6(9), 4346-4351.

Sateu D., Malutan T., Bilba D., 2011. Agricultural waste corn cob as a sorbent for removing reactive dye Orange 16: Equilibrium and kinetic study. Cellulose Chem. Technol., 45(5-6), 413-420.

Sočo E., Kalembkiewicz J., 2016. Comparison of adsorption of $\mathrm{Cd}(\mathrm{II})$ and $\mathrm{Pb}$ (II) ions on pure and chemically modified fly ashes. Chem. Proc. Eng., 37(2), 215-234. DOI: 10.1515/cpe-2016-0018.

Soldatkina L. M. , Sagaidak E. V., Menchuk V. V., 2009. Adsorption of cationic dyes from aqueous solutions on sunflower husk. J. Wat. Chem. Technol., 31, 238-243. DOI: 10.3103/S1063455X09040055. 
Srinivasan A., Viraraghavan T., 2010. Oil removal from water using biomaterials. Biores. Technol., 101, 65946600. DOI: 10.1016/j.biortech.2010.03.079.

Sud D., Mahajan G., Kaur M.P., 2008. Agricultural waste material as potential adsorbent for sequestering heavy metal ions from aqueous solutions - A review. Biores. Technol., 99, 6017-6027. DOI: 10.1016/j.biortech.2007.11.064.

Tomczak E., 2013. Water purification from heavy metal ions in a packed column. Sep. Sci. Technol., 48, 22702276. DOI: $10.1080 / 01496395.2013 .805224$.

Tomczak E., Kamiński W., Tosik P., 2015. Adsorption dynamics studies of azo dyes removal by biosorbent. Desalin. Wat. Treat. 55, 2669-2674. DOI: 10.1080/19443994.2014.939490.

Tomczak E., Tosik P., 2014, Sorption equilibrium of azo dyes Direct Orange 26 and Reactive Blue 81 onto a cheap plant sorbent. Ecol. Chem. Eng S, 21, 435-445. DOI: 10.2478/eces-2014-0032.

Volesky B., 2007. Biosorption and me. Wat. Res., 41, 4017-4029. DOI: 10.1016/j.watres.2007.05.062.

Witek-Krowiak A., 2012. Analysis of temperature-dependent biosorption of $\mathrm{Cu}^{2+}$ ions on sunflower hulls: Kinetics, equilibrium and mechanism of the process. Chem. Eng. J., 192, 13-20. DOI: 10.1016/j.cej.2012.03.075.

Xu Zhe, Cai Jian-guo, Pan Bing-cai. 2013. Mathematically modeling fixed-bed adsorption in aqueous systems. Appl. Phys. Eng., 14(3), 155-176. DOI: 10.1631/jzus.A1300029.

Yasmen A.M., Shahlaa E.E., 2010. Utilization of Thomas model to predict the breakthrough curves for adsorption and ion exchange. J. Eng., 16(4), 6206-6223.

Received 11 January 2017

Received in revised form 24 March 2017

Accepted 20 April 2017 